\title{
IMPACTOS DO CPC/2015 NO PROCESSO DO TRABALHO: ENFOQUE NA PROVA PERICIAL
}

\author{
IMPACTS OF 2015/2015 IN THE WORK PROCESS: A FOCUS ON THE PERIODIC \\ PROOF
}

Saulo Cerqueira de Aguiar Soares ${ }^{1}$

\section{RESUMO}

O artigo versa sobre os impactos do novo Código de Processo Civil de 2015 no processo do trabalho, com base no neoprocessualismo, valorizando sua interpretação com enfoque na Constituição Federal. Como objetivo geral, buscou-se com o estudo canalizar um olhar questionador a respeito das alterações advindas pelo novel código processual comum na seara do processo trabalhista, refletindo sobre as inovações e aplicabilidades. Quanto a metodologia empregada, esta caracteriza-se como uma investigação teórico-documental perante uma perspectiva doutrinária e legal. Ao final da pesquisa concluiu-se que foram significativos os reflexos do Código de Processo Civil de 2015 no processo do trabalho, cabendo a jurisprudência trabalhista promover seu aperfeiçoamento, em sintonia com a preservação da segurança jurídica, condição essencial em uma sociedade democrática.

Palavras-chave: Direito Processual do Trabalho. Código de Processo Civil. Justiça do Trabalho.

\section{ABSTRACT}

The article deals with the impacts of the new Civil Procedure Code of 2015 on the labor process, based on neoprocessalism, valuing its interpretation with a focus on the Federal Constitution. As a general objective, the study sought to channel a questioning look at the alterations of the novel common procedural code in the labor process, reflecting on innovations and applicabilities. As for the methodology employed, this is characterized as a theoretical-documentary investigation from a doctrinal and legal perspective. At the end of the research it was concluded that the reflexes of the Code of Civil Procedure of 2015 in the labor process were significant,

1 Doutorando e Mestre Magna cum Laude em Direito do Trabalho - PUC/MG. Especialista em Medicina do Trabalho e Direito do Trabalho. Médico do Trabalho. Advogado. Professor. E-mail: saulocerqueira@hotmail.com.br 
and it is up to labor jurisprudence to promote its improvement, in harmony with the preservation of legal security, an essential condition in a democratic society.

Keywords: Labor Law. Code of Civil Procedure. Work justice.

\section{INTRODUÇÃO}

A Lei $n^{\circ}$ 13.105, de 16 de março de 2015 instituiu o Novo Código de Processo Civil (CPC de 2015), ficando revogada a Lei $n^{\circ}$ 5.869, de 11 de janeiro de 1973, nos termos do art. 1.046, tendo sua vigência somente um ano após sua publicação oficial, ou seja, no dia 18 de março de 2016.

O CPC de 2015 é ordenado em parte geral e parte especial, perfazendo a primeira com seis livros, aos quais são: normas processuais civis; função jurisdicional; sujeitos do processo; atos processuais; tutela provisória; formação, suspensão e extinção do processo; à medida que a parte especial é formada por três livros: processo de conhecimento e cumprimento de sentença; processo de execução e processos nos tribunais e meios de impugnação das decisões judiciais; finalizando com um livro complementar, as disposições finais e transitórias.

O CPC de 2015 apresenta impactos no processo do trabalho, em uma relação que cabe apuração entre o Direito Processual Civil e o Direito Processual do Trabalho, estudando seu alcance e significado, o que se realiza de modo não extenuante.

A metodologia do presente trabalho caracteriza-se como uma investigação teórico-documental perante uma perspectiva doutrinária e legal, aplicada como roteiro, com revisão bibliográfica, abordando aspectos relevantes dos reflexos do CPC de 2015 e da Lei $n^{\circ}$ 13.467/2017 (Reforma Trabalhista) no processo do trabalho, com enfoque especial nas alterações que concernem a prova pericial. 


\section{A INSTRUÇÃO NORMATIVA N 39/2016 DO TRIBUNAL SUPERIOR DO TRABALHO}

A Resolução $n^{\circ}$ 203, de 15 de março de 2016, do Tribunal Superior do Trabalho (TST), editou a Instrução Normativa $n^{\circ} 39$, que dispõe sobre as normas do Código de Processo Civil de 2015 aplicáveis e inaplicáveis ao Processo do Trabalho, de forma não exaustiva.

Determinou 0 art. $1^{\circ}$ da Instrução Normativa $n^{\circ} 39$ do TST que aplica-se 0 Código de Processo Civil, subsidiária e supletivamente, ao Processo do Trabalho, em caso de omissão e desde que haja compatibilidade com as normas e princípios do Direito Processual do Trabalho, na forma dos artigos 769 e 889 da Consolidação das Leis do Trabalho (CLT) e do art. 15 da Lei n 13.105, de 17.03.2015.

Cabe destacar a autonomia jurídica do Direito Processual Civil ao Direito Processual do Trabalho. No Brasil, diferentemente de alguns países do Mercado Comum do Sul (MERCOSUL) não há um Código de Processo do Trabalho, o que poderia facilitar a aplicação da norma jurídica processual no país de forma mais célere; assim, aplica-se a disposição do artigo 769 da Consolidação das Leis do Trabalho (CLT), ao definir que "nos casos omissos, o direito processual comum será fonte subsidiária do direito processual do trabalho, exceto naquilo em que for incompatível com as normas deste Título". Desse modo, se define a aplicação subsidiária do Direito Processual Comum no processo do trabalho quando presente a omissão e a compatibilidade.

Nessa matéria, avalia Gustavo Filipe Barbosa Garcia (2017) que:

cabe salientar que para essa aplicação subsidiária não é suficiente que haja lacuna na Consolidação das Leis do Trabalho, mas sim a omissão nas normas jurídicas do processo do trabalho, sabendo-se que há diversos outros diplomas legais a respeito da matéria, como a Lei 5.584/1970 e a Lei 7.701/1988. (GARCIA, 2017, p. 24).

Com o art. 15 do CPC de 2015 ficou previsto, agora, a aplicação não somente subsidiária, mas também supletiva do Processo Civil Comum ao Processo do 
Trabalho. Entende-se como aplicação subsidiária a que é realizada quando no caso de omissão completa das normas processuais trabalhistas sobre determinada questão; enquanto a aplicação supletiva se dá de forma a complementar algo já previsto, em uma omissão parcial da norma processual trabalhista.

Compreende Mauro Schiavi (2016) que

o fato de o novo código se aplicar subsidiária e supletivamente (art. 15 do CPC) ao Processo Trabalhista não significa que seus dispositivos sejam aplicados, simplesmente, nas omissões da lei processual do trabalho, ou incompletude de suas disposições, mas somente quando forem compatíveis com o sistema trabalhista e também propiciarem melhores resultados à jurisdição trabalhista. (SCHIAVI, 2016, p. 157).

Abordando a Instrução Normativa n 39/2016 do TST, cabível observar, em todo caso, o princípio da irrecorribilidade em separado das decisões interlocutórias, de conformidade com o art. 893, $\S 1^{\circ}$ da CLT e Súmula n 214 do TST.

$\mathrm{E}$, destaca que o prazo para interpor e contra-arrazoar todos os recursos trabalhistas, inclusive agravo interno e agravo regimental, é de oito dias (art. $6^{\circ}$ da Lei $n^{\circ}$ 5.584/70 e art. 893 da CLT), exceto embargos de declaração (CLT, art. 897A).

Como dispositivos do CPC de 2015 compreendidos como inaplicáveis ao Processo do Trabalho, nos termos do art. $2^{\circ}$ da referida Instrução Normativa $n^{\circ}$ 39/2016 do TST, de forma exemplificativa, são:

I - art. 63 (modificação da competência territorial e eleição de foro);

II - art. 190 e parágrafo único (negociação processual);

III - art. 219 (contagem de prazos em dias úteis);

IV - art. 334 (audiência de conciliação ou de mediação);

$\mathrm{V}$ - art. 335 (prazo para contestação);

VI - art. 362, III (adiamento da audiência em razão de atraso injustificado superior a 30 minutos);

VII - art. 373, §§ $3^{\circ}$ e $4^{\circ}$ (distribuição diversa do ônus da prova por convenção das partes);

VIII - arts. 921 , §§ $4^{\circ}$ e $5^{\circ}$, e 924, V (prescrição intercorrente);

IX - art. 942 e parágrafos (prosseguimento de julgamento não unânime de apelação);

$X$ - art. 944 (notas taquigráficas para substituir acórdão);

XI - art. 1010, $\S 3^{\circ}$ (desnecessidade de o juízo a quo exercer controle de admissibilidade na apelação); 
XII - arts. 1043 e 1044 (embargos de divergência);

XIII - art. 1070 (prazo para interposição de agravo).

(BRASIL, TST, IN. 39/2016).

Conforme se examina do art. 775 da CLT, acerca da contagem de prazos, contam-se com exclusão do dia do começo e inclusão do dia do vencimento, e são contínuos e irreleváveis, podendo, entretanto, ser prorrogados pelo tempo estritamente necessário pelo juiz ou tribunal, ou em virtude de força maior, devidamente comprovada. E, o inc. III do art. $2^{\circ}$ da Instrução Normativa n 39/2016 do TST entendeu ser inaplicável ao processo do trabalho o art. 219 do CPC de 2015, que estabelece a contagem somente em dias úteis.

Acontece que com a Lei $n^{\circ} 13.467 / 2017$ foi alterada a redação do art. 775 da CLT, estabelecendo que "os prazos estabelecidos neste Título serão contados em dias úteis, com exclusão do dia do começo e inclusão do dia do vencimento". Assim, fica desatualizado o supracitado item da Instrução Normativa $n^{\circ} 39 / 2016$ do TST, promovendo, agora, uma harmonia do processo do trabalho com o processo civil, na contagem dos prazos processuais.

Uma questão a ser analisada detalhadamente é que a nova redação do art. 775 da CLT define que somente os prazos no título $X$ - Do Processo Judiciário do Trabalho serão contados em dias úteis, não determinando que em demais ações que podem percorrer a esfera trabalhista terão sua contagem em dias úteis, como a exemplo da Ação Civil Pública, regulada pela Lei $n^{\circ} 7.347 / 1985$; o que merece uma definição posterior.

A Instrução Normativa n³9/2016 do TST, determinou a não aplicação do art. 362, inciso II do CPC de 2015, referente ao adiamento da audiência em razão de atraso injustificado superior a 30 minutos, diante de que o parágrafo único do art. 815 da CLT é claro em definir se, até 15 (quinze) minutos após a hora marcada, o juiz ou presidente não houver comparecido, os presentes poderão retirar-se, devendo o ocorrido constar do livro de registro das audiências. Nesse assunto, é pertinente registrar que não são atípicas as situações que ocorrem atrasos superiores a 15 minutos, e tendo conhecimento dessa condição a secretaria da Vara 
se nega a abrir o balcão de atendimento ao advogado e aos jurisdicionados para que registrem no livro de registro das audiências seu comparecimento e o atraso injustificado do juiz. Esse comportamento não se mostra transparente, pois por uma via oblíqua se impede o exercício do direito do jurisdicionado e se promove uma violação legal, de modo a impossibilitar o fiel registro do ocorrido, fazendo que com que as partes fiquem em tempo superior ao regulamentado aguardando o comparecimento do juiz para a audiência, enquanto, em determinado casos, a secretaria faz negativa de atendimento.

Prosseguindo o estudo, define 0 art. $3^{\circ}$ da Instrução Normativa $n^{\circ}$ 39/2016 do TST que sem prejuízo de outros, aplicam-se ao Processo do Trabalho, em face de omissão e compatibilidade, os preceitos do Código de Processo Civil que regulam os seguintes temas:

I - art. 76 , $\S \S 1^{\circ}$ e $2^{\circ}$ (saneamento de incapacidade processual ou de irregularidade de representação);

II - art. 138 e parágrafos (amicus curiae);

III - art. 139, exceto a parte final do inciso V (poderes, deveres e responsabilidades do juiz);

IV - art. 292, V (valor pretendido na ação indenizatória, inclusive a fundada em dano moral);

V - art. 292, § $3^{\circ}$ (correção de ofício do valor da causa);

VI - arts. 294 a 311 (tutela provisória);

VII - art. 373, §§ $1^{\circ}$ e $2^{\circ}$ (distribuição dinâmica do ônus da prova); VIII - art. $485, \S 7^{\circ}$ (juízo de retratação no recurso ordinário);

IX - art. 489 (fundamentação da sentença);

X - art. 496 e parágrafos (remessa necessária);

XI - arts. 497 a 501 (tutela específica);

XII - arts. 536 a 538 (cumprimento de sentença que reconheça a exigibilidade de obrigação de fazer, de não fazer ou de entregar coisa);

XIII - arts. 789 a 796 (responsabilidade patrimonial);

XIV - art. 805 e parágrafo único (obrigação de o executado indicar outros meios mais eficazes e menos onerosos para promover a execução);

XV - art. 833, incisos e parágrafos (bens impenhoráveis);

$\mathrm{XVI}$ - art. 835, incisos e $\S \S 1^{\circ}$ e $2^{\circ}$ (ordem preferencial de penhora);

XVII - art. 836, $\S \S 1^{\circ}$ e $2^{\circ}$ (procedimento quando não encontrados bens penhoráveis);

maior);

XVIII - art. 841, §§ $1^{\circ}$ e $2^{\circ}$ (intimação da penhora);

XIX - art. 854 e parágrafos (BacenJUD);

$X X$ - art. 895 (pagamento parcelado do lanço);

XXI - art. 916 e parágrafos (parcelamento do crédito exequendo);

XXII - art. 918 e parágrafo único (rejeição liminar dos embargos à execução); XXIII - arts. 926 a 928 (jurisprudência dos tribunais); 
XXIV - art. 940 (vista regimental);

XXV - art. 947 e parágrafos (incidente de assunção de competência);

XXVI - arts. 966 a 975 (ação rescisória);

XXVII - arts. 988 a 993 (reclamação);

XXVIII - arts. 1013 a 1014 (efeito devolutivo do recurso ordinário - força

XXIX - art. 1021 (salvo quanto ao prazo do agravo interno). (BRASIL, TST, IN 39/2016).

No que tange a intervenção de terceiros, incumbe tratar do amicus curie, prevista no ordenamento processual desde a Lei n $9.868 / 1999$. Fica disposto que é possível a atuação do amicus curie a partir das Varas do Trabalho, cabendo ao juiz, de forma fundamentada, a decisão de admitir sua intervenção. Tal participação é fundamental em matérias, por exemplo, pertinentes a saúde e segurança dos trabalhadores, com repercussão de natureza coletiva, em que já nas Varas do Trabalho deveriam ter melhor embasamento sobre essa área, além de tudo, pelo Brasil alçar o título de quarto colocado no mundo em número de acidentes do trabalho.

Quanto a distribuição dinâmica do ônus da prova, o art. 373 do CPC de 2015 e o art. 818 da CLT definem que cabe ao reclamante no que se refere ao fato constitutivo de seu direito e ao réu no que tange a existência de fato impeditivo, modificativo ou extintivo do direito do autor. Disciplina o $\S 1^{\circ}$ do art. 373 do CPC que nos casos previstos em lei ou diante de peculiaridades da causa relacionadas à impossibilidade ou à excessiva dificuldade de cumprir o encargo nos termos do caput ou à maior facilidade de obtenção da prova do fato contrário, poderá o juiz atribuir o ônus da prova de modo diverso, desde que o faça por decisão fundamentada, caso em que deverá dar à parte a oportunidade de se desincumbir do ônus que Ihe foi atribuído; refletindo a existência da distribuição dinâmica do ônus da prova.

Consoante o estabelecido no art. $8^{\circ}$ da Instrução Normativa 39/2016 do TST, aplicam-se ao Direito Processual do Trabalho as disposições que regulam o incidente de resolução de demandas repetitivas (IRDR), designados nos artigos 976 a 986 do CPC de 2015; sendo que a tese jurídica adotada pelo TST deve ser 
aplicada a todos os processos no país, quando versem sobre idêntica questão de direito, por entendimento do $\S 3^{\circ}$ da referida Instrução Normativa.

\section{IMPACTOS DO CPC DE 2015 E DA REFORMA TRABALHISTA NA PERÍCIA TRABALHISTA}

Em concordância com o art. 464 do CPC a prova pericial consiste em exame, vistoria ou avaliação. O exame ocorre em pessoa, coisa ou semovente; a vistoria, em coisa imóvel ou lugares; e avaliação em bem móvel, estimando o valor de coisas, bens ou obrigações. Acomoda-se uma quarta modalidade, de discussão doutrinária, que é o arbitramento, aplicável quando da necessidade de verificar o valor do objeto do litígio.

$\mathrm{Na}$ área da saúde, é corriqueiro que a perícia se refira sobre a própria parte, ao investigar, por exemplo, a capacidade laboral após um acidente do trabalho ou doença ocupacional. Nessa condição, a parte não é obrigada a se submeter a um exame pericial, pois violaria sua intimidade e privacidade, assim como o profissional que assim agisse transgrediria normas éticas de sua profissão. Dessa maneira, o celeuma se resolve com a aplicação do art. 232 do Código Civil, que define que "a recusa à perícia médica ordenada pelo juiz poderá suprir a prova que se pretendia obter com o exame".

Nova modificação na seara do meio de prova em estudo é a perícia consensual. A disposição presente no art. 471 do CPC de 2105 trata de um negócio jurídico processual, situação que em comum acordo as partes fazem a escolha do Perito. Trata-se de uma cooperação entre as partes para em acordo indicarem o perito, sendo que a perícia consensual substitui, para todos os efeitos, a que seria realizada pelo perito nomeado pelo juiz, nos termos do $\S 3^{\circ}$ do supracitado artigo.

A perícia consensual exige como requisitos mínimos que as partes sejam plenamente capazes e a causa possa ser resolvida por autocomposição.

Compreende-se que o direito das partes escolherem o Perito têm limitações, frente a previsão de existência do cadastro do tribunal, sendo indispensável que a 
seleção recaia sobre perito constante desse arquivo. A cooperação que enseja a perícia consensual não pode violar as próprias normativas do atual Código, pois é mandatório a disponibilização dos documentos exigidos para habilitação do perito à consulta de quaisquer interessados, em uma abordagem do processo democrático.

O trabalho do Perito do Juízo se materializa no laudo pericial, que é resultado das diligências que realizou em estudo com literatura científica.

O atual Código inovou ao adentrar na seara técnica da prova pericial, ao estabelecer pontualmente qual o formato do laudo pericial, conforme o art. 473, que define que:

Art. 473. O laudo pericial deverá conter:

I - a exposição do objeto da perícia;

II - a análise técnica ou científica realizada pelo perito;

III - a indicação do método utilizado, esclarecendo-o e demonstrando ser predominantemente aceito pelos especialistas da área do conhecimento da qual se originou;

IV - resposta conclusiva a todos os quesitos apresentados pelo juiz, pelas partes e pelo órgão do Ministério Público.

(BRASIL, CPC, 2015).

Essa exigência de forma e conteúdo delimitados é questionável do ponto de vista científico, pois ao mesmo tempo que possibilita uma isonomia metodológica entre laudos periciais, engessa a formação do laudo pericial nas diversas áreas do conhecimento, que estão em constante atualização. Mais adequado seria se o CPC não adentrasse na técnica pericial, mas sim definisse somente critérios jurídicos, visto que cabe a cada campo científico promover a definição técnica da formação de um laudo pericial, inclusive por meio de resoluções de conselhos de classe profissional.

Não cabe ao legislador definir questões eminentemente técnicas do laudo pericial, dado que inviabiliza o avanço científico de cada área do conhecimento que se utiliza da perícia como meio de atuação.

A título exemplificativo, a perícia médica, conforme a Resolução $n^{\circ}$ 2.056/2013 do Conselho Federal de Medicina (CFM), tem a estrutura do laudo 
pericial definida em seu art. 58, devendo o roteiro básico do relatório pericial conter preâmbulo, individualização da perícia, circunstâncias do exame pericial, identificação do examinando, história da doença atual, história pessoal, história médica, história familiar, exame físico, exames e avaliações complementares, diagnóstico positivo, comentários médico-legais, conclusão e respostas aos quesitos.

Ao que se constata cabe a cada órgão profissional estabelecer critérios técnicos de atuação pericial, com meios de alteração mais satisfatórias do que os requerem as mudanças legislativas.

O Perito do Juízo é sujeito imprescindível para a solução e a pacificação por meio do processo, perante que sendo um auxiliar eventual do Juízo coopera com o magistrado nas situações em que a prova do fato litigioso carece de um estudo científico ou técnico. Quando de perícia complexa, ao abordar mais de uma área de conhecimento, pode o juiz inclusive nomear mais de um perito.

Destaca Humberto Theodoro Júnior (2016) que

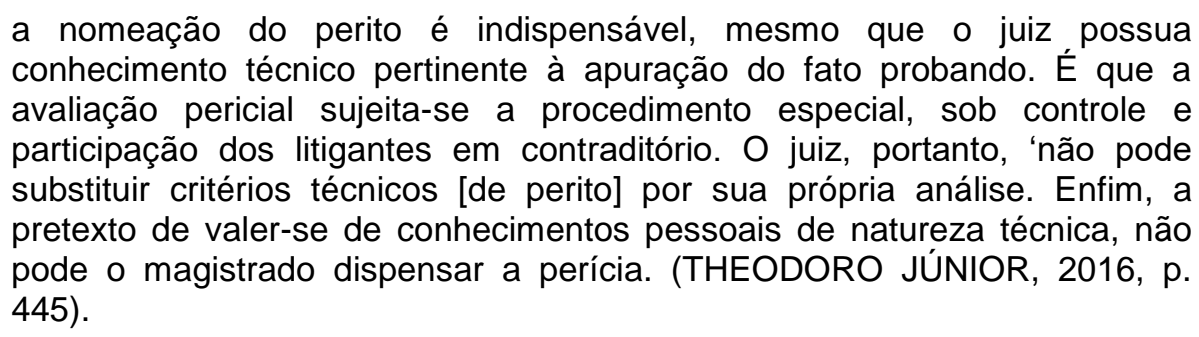

Condição processualmente indevida é a que homologa acordo entre as partes, após a realização do exame pericial, definindo o responsável pelo pagamento dos honorários periciais e o valor, sem antes de realizar uma oitiva do Perito do Juízo a respeito. A fixação dos honorários periciais, por se tratar de um direito de terceiro, o Perito do Juízo, sujeito imparcial do processo, deve ouvir se o ilustre expert concorda com o valor atribuído de honorários periciais, não podendo as partes nem o Juízo dispor de tal direito sem seu consentimento expresso. A prática forense vem revelando uma séria burla ao pagamento dos honorários periciais por meio desses acordos entabulados de modo eticamente questionáveis, 
tendo em vista que após a reclamada ter um laudo pericial desfavorável a seus interesses e demonstrar interesse por promover um acordo com a parte reclamante, de modo a por fim ao processo e evitar a sucumbência esperada no objeto do pedido da perícia, busca deslocar a responsabilidade do pagamento dos honorários periciais para a União, tudo isso com o consentimento do Juiz, que com o objetivo de atingir as metas propostas de acordo, indevidamente aumenta os encargos da União de forma despropositada. Assim, o Perito do Juízo que seria remunerado pela reclamada, que provavelmente seria a parte sucumbente no objeto da perícia, passa a ter que aguardar requisição de honorários periciais do Tribunal, até mesmo em valor inferior do que seria arbitrado se por responsabilidade da reclamada.

Infelizmente, se tem vivenciado que mesmo quando a requisição de honorários pericias pela União é em valor superior ao estabelecido ordinariamente pelo CSJT pelo Juiz do feito, a figura do Presidente do Tribunal Regional, a quem compete tal determinação, pode impedir sua escorreita requisição, de forma injusta, por mera comunicação ao servidor da Vara do Trabalho responsável pela requisição, reduzindo o valor arbitrado de honorários periciais, que já foi atingido pela coisa julgada. Vem ocorrendo, silenciosamente, um desrespeito ao devido processo legal no que concerne ao pagamento dos honorários periciais por crédito da União. Não há como simplesmente se negar a determinação da requisição tornando impossível o recebimento do crédito de natureza alimentar pelo relevante profissional que exerceu a função de Perito do Juízo. A falta de representatividade de um corpo de peritos na organização dos Tribunais do Trabalho explicitam uma face obscura do processo trabalhista, que resvala na qualidade da prova pericial, no trabalho precário e na própria administração da Justiça.

Cumpre salientar que o CPC de 2015 regula que não se deve proferir decisão contra uma das partes sem que ela seja previamente ouvida. Conforme o art. 10 do CPC de 2015 o juiz não pode decidir, em grau algum de jurisdição, com base em fundamento a respeito do qual não se tenha dado às partes oportunidade de se manifestar, ainda que se trate de matéria sobre a qual deva decidir de ofício. Deve- 
se flexibilizar positivamente tal determinação legal, aplicando não somente as partes em sentido estrito, mas aos sujeitos processuais, como o Perito do Juízo.

Fredie Didier Jr. (2017) avança ainda mais ao entender que o Perito do Juízo caso não seja compreendido como terceiro prejudicado é mesmo uma parte do processo, o que revela

\begin{abstract}
em relação a tais questões, pode-se afirmar que estas pessoas (auxiliares e juiz) são partes, porquanto sofram diretamente as consequências de uma decisão, exarada após um procedimento (maior ou menor; em autos apartados, ou não; pouco importa) de que participaram, ou poderiam participar. O núcleo da discussão é precisar-se o conceito de parte. Não se pode restringir esta noção apenas às figuras do autor e do réu (quem e em face de quem se pede a prestação jurisdicional). [...] Assim, a legitimidade de recurso pelo juiz ou pelos auxiliares será na condição de parte - e não de terceiro-, nos incidentes que reflitam sobre seus interesses. A taxinomia é fundamental para que se evitem deslizes. (DIDIER JR., 2017, grifo nosso).
\end{abstract}

No que concerne ao posicionamento adotado acerca dos honorários periciais no processo do trabalho é uma condição estarrecedora, visto a CLT ser parcialmente omissa e o CPC de 2015 compatível. É necessário aplicar o CPC de 2015 na temática dos honorários periciais, garantindo o depósito prévio, nos moldes do processo comum, do que estabelece o $\S 4^{\circ}$ do art. 465 que "o juiz poderá autorizar o pagamento de até cinquenta por cento dos honorários arbitrados a favor do perito no início dos trabalhos, devendo o remanescente ser pago apenas ao final, depois de entregue o laudo e prestados todos os esclarecimentos necessários."

A Lei $n^{\circ}$ 13.467, de 13 de julho de 2017, nomeada de Reforma Trabalhista, veio a modificar radicalmente a matéria de honorários periciais na Justiça do Trabalho, prejudicando sobremaneira a atividade do Perito do Juízo Trabalhista, em níveis antes nunca suportados, com a finalidade de reduzir drasticamente o número de demandas atinentes a acidentes do trabalho, doenças ocupacionais, adicional de insalubridade, periculosidade e perícia ergonômica.

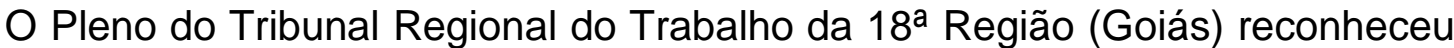
a legalidade do depósito prévio para realização da perícia, alterando, acertadamente, o entendimento a respeito na inexigibilidade do adiantamento dos 
honorários periciais. Foram julgados mandados de segurança que questionavam decisões de primeiro grau que determinavam a reclamadas proceder o adiantamento dos honorários periciais para os custos iniciais da realização da prova pericial, tendo sido todas a segurança denegada.

Ocorre que o adiantamento de honorários periciais é verba de natureza alimentar para a pessoa do Perito do Juízo, cabendo ser deferida sob pena da impossibilidade de se realizar a prova pericial, por se tratar de prestação pecuniária que visa a sobrevivência da pessoa, com supedâneo no princípio da dignidade da pessoa humana e na valorização do trabalho humano, com supedâneo no art. $1^{\circ}$, inciso III c/c art. 170, caput, ambos da Constituição Federal de 1988) ainda com base em que as partes tem o dever de colaborar com a Justiça, inteligência dos artigos 77, inciso IV e 378, ambos do CPC de 2015.

Sabiamente, evidenciando o zelo e aplicação perfeita da matéria processual, o Egrégio TRT da 18ª Região determinou que o art. 95 do CPC de 2015 regulamenta o adiantamento dos honorários periciais, não sendo incompatível com o art. 790-B da CLT.

Ressaltou o eminente relator, no supracitado julgamento (2016) que:

o adiantamento não se confunde com o pagamento e poderá ser revertido à parte que o procedeu, pelos meios próprios, inclusive com recursos públicos, quando o sucumbente na pretensão objeto da prova é beneficiário de gratuidade da justiça. (TRT-18 Região, MS - 10445-95.2016.5.18.0000, Rel. Paulo Pimenta, 2016).

O entendimento límpido foi o de que a Orientação Jurisprudencial $n^{\circ} 98$ da SDI-2 do Tribunal Superior do Trabalho (TST) encontra-se superada com a vigência do CPC de 2015, diante de existir previsão legal da antecipação dos honorários periciais pela reclamada, não havendo mais do que se falar em incompatibilidade com o Direito Processual do Trabalho.

Ao que se verifica, desde o dia 18 de março de 2016, data da entrada em vigência do CPC de 2015, encontra-se em total compatibilidade com o processo do trabalho o adiantamento dos honorários periciais. Porém, por insciência da matéria 
ou por falta de interesse em garantir uma prestação jurisdicional que respeite o trabalho do Perito Judicial Trabalhista, o Poder Judiciário Trabalhista, em grande ala, desrespeita o direito do Perito Judicial receber o adiantamento conforme o art. 95 do CPC, fazendo que suporte o pesado ônus de trabalhar gratuitamente, assumindo totalmente os riscos de sua atividade econômica e os custos iniciais para a realização da prova pericial, para ter acesso ao seu crédito somente após o longo trânsito em julgado. Nesse exemplo observa-se claramente que mesmo no vigor do CPC de 2015 o Tribunal Superior do Trabalho, de forma claramente errônea, não cancelou a OJ 98 da SDI-2 do TST, o que agrava o trabalho precário do Perito Judicial Trabalhista, tônica pouco levantada nos estudos científicos, e que cabe bastante cautela, diante das condições de trabalho sem qualquer segurança de continuidade que os Peritos Judiciais da Justiça do Trabalho se expõem, não sendo agasalhados no quadro permanente de servidores.

A Lei $n^{\circ} 13.467$, de 13 de julho de 2017, em violação da busca constante progresso social, acrescentou o $\S 3^{\circ}$ ao art. 790-B da CLT, dispondo que "o juízo não poderá exigir adiantamento de valores para realização de perícias." O relatório do substitutivo do projeto de lei que culminou na Reforma Trabalhista admitiu que a finalidade é a segurança dos empregadores, enquanto vem realizar a precarização das condições de trabalho para os moldes anteriores da Revolução Industrial.

Dispõe abertamente o relatório do anunciado substitutivo que:

\begin{abstract}
o fato é que, hoje, a União custeia, a título de honorários periciais, valores entre dez a vinte milhões de reais por ano, para cada um dos vinte e quatro Tribunais Regionais do Trabalho, somente em relação a demandas julgadas improcedentes, ou seja, demandas em que se pleiteou o que não era devido. Na medida em que a parte tenha conhecimento de que terá que arcar com os custos da perícia, é de se esperar que a utilização sem critério desse instituto diminua sensivelmente. Além de contribuir para a diminuição no número de ações trabalhistas, a medida representará uma redução nas despesas do Poder Judiciário, que não mais terá que arcar com os honorários periciais. (BRASIL, Substitutivo ao Projeto de Lei n 6787/2016).
\end{abstract}

Portanto, fica claro, em declaração pública, que a efetiva intenção é reduzir os pedidos de realização de perícia na Justiça do Trabalho, assim como menosprezar a 
carreira pericial exercida por peritos judiciais e assistentes técnicos, afetando inúmeros profissionais, como médicos, engenheiros, fisioterapeutas, fonoaudiólogos, contabilistas, e todos demais que realizam perícias na Justiça do Trabalho.

Essa mudança promoverá uma uberização dos peritos da Justiça do Trabalho, estabelecendo um teto vil de honorários, impedindo o adiantamento legítimo.

$\mathrm{Na}$ matéria do arbitramento dos honorários médicos periciais, no conflito da aplicação do CPC de 2015 com a Lei n’ 13.467/2017, destaca-se que da data do requerimento da prova pericial médica ou da determinação da nomeação do Perito do Juízo que se delimita a lei aplicável, por ordem do artigo 1.047 do CPC de 2015, por os honorários periciais decorrerem da prova pericial, por isso, disposição de direito probatório. Desse modo, ressalta-se que não é aplicável a limitação do valor estabelecida pelo CSJT do $\$ 1^{\circ}$ do art. $790-B$ da redação dada pela Lei $\mathrm{n}^{\circ}$ 13.467/2017, por força do art. 1.047 do CPC, quando de qualquer perícia determinada anteriormente a data de 11 de novembro de 2017, entrada em vigência da Lei $n^{\circ} 13.467 / 2017$.

Entende Sebastião Geraldo de Oliveira (2013) que

\begin{abstract}
a diligência pericial envolvendo acidente do trabalho [e, 0 art. 20 da Lei $n^{\circ}$ 8.213/1991 equipara as doenças ocupacionais, anotação nossa] será mais demorada e trabalhosa, com laudos extensos, pelo que deve merecer por parte dos magistrados, o arbitramento de honorários condizentes para remunerar adequadamente o perito oficial, certamente bem acima dos valores fixados para os laudos envolvendo adicional de insalubridade e periculosidade. (OLIVEIRA, 2013, p. 327).
\end{abstract}

Compreende Daniel Amorim Assumpção Nunes (2015, p.554) que "é indiscutível que a prova pericial é o meio de prova mais complexo, demorado e caro de todo o sistema probatório".

A Reforma Tarbalhista ainda prever o parcelamento dos honorários periciais, o que prejudica sobremaneira o Perito, que assume os custos de modo integral.

Tal circunstância é mais uma depreciação com o Perito Judicial, juntamente com o dispositivo que proíbe o adiantamento de valores para a viabilização da 
realização de perícias. Ora, se os peritos judiciais trabalhistas não são servidores públicos concursados, deveram assumir o ônus das custas iniciais para a realização da perícia judicial? É algo imponderado, que viola o acesso a jurisdição, pois simplesmente afugenta os peritos mais capacitados da atividade, prejudicando a administração da Justiça.

Exigir que o perito judicial arque com os custos sem adiantamento é exigir que subministre meios para atender às despesas do litígio, sendo justamente uma causa de suspeição disposta no inc. II do art. $145 \mathrm{c} / \mathrm{c}$ inc. III do art. 148, ambos do CPC de 2015.

Em nosso sentir, mesmo com a redação dada pelo $\S 3^{\circ}$ ao art. $790-B$ da CLT é possível, licitamente, sustentar o adiantamento dos honorários periciais. Vejamos, diante da determinação da nomeação de um Perito Judicial Trabalhista cabe o Juiz do feito imediatamente solicitar a requisição ao Presidente do Tribunal para o pagamento das despesas iniciais, o que inclusive já está previsto no $\S 2^{\circ}$ do art. $2^{\circ}$ da Resolução $n^{\circ}$ 66, de 10 de junho de 2010 do Conselho Superior da Justiça do Trabalho (CSJT). Assim, após o trânsito em julgado, a parte sucumbente no objeto da perícia que deve ressarcir a União do pagamento já realizado, não infringindo de qualquer modo, tal entendimento, as normativas legais.

Estabelece o art. 790-B, $\S 1^{\circ}$ que "Ao fixar o valor dos honorários periciais, o juízo deverá respeitar o limite máximo estabelecido pelo Conselho Superior da Justiça do Trabalho."

Tal dispositivo é uma afronta com todos os profissionais trabalhadores que são peritos judiciais, limitando os honorários periciais ao teto da Resolução $n^{\circ} 66$, de 10 de junho de 2010 , do CSJT, que é de $R \$ 1.000,00$, violando o princípio da equidade, de quantificar o valor do trabalho pericial com base na complexidade da matéria, no grau de zelo e de especialização do profissional, pois se detentor de título de mestrado ou doutorado deve receber uma gratificação superior (por analogia da Lei $n^{\circ}$ 11.416/2006), nas despesas para a manutenção do consultório/escritório, nos custos para eventual realização da inspeção do meio ambiente de trabalho e no tempo que o perito tem de aguardar entre a realização do 
trabalho pericial e o recebimento dos honorários periciais. Não há como se realizar a aplicação desvairada da atual redação do art. 790-B, § $1^{\circ}$ da CLT. Não há dúvidas que Peritos do Juízo em matérias de acidentes do trabalho e doenças ocupacionais tem dispêndio econômico alto somente para a realização de uma prova pericial, da anamnese médica, da eventual inspeção do local de trabalho, conforme disposto acima, afora todo o preparo profissional para se tornar Perito.

Ainda, ressalta-se que de 10 de junho de 2010 (entrada em vigor da Resolução n 66 do CSJT) à data atual de 2017, a inflação medida pelo IPCA (Índice Nacional de Preços ao Consumidor Amplo) do Instituto Brasileiro de Geografia e Estatística (IBGE) chegou a $56,01 \%$. Isto significa que se o valor do teto do arbitramento dos honorários periciais fosse atualizado somente para corrigir as perdas inflacionárias desse período, deveria ser no valor de $R \$ 1.560,11$. Não há como sustentar a não atualização monetária no arbitramento do teto dos honorários periciais a serem quitados pela União ou pelas partes, cabendo o art. 790-B, $\S 1^{\circ} \mathrm{da}$ CLT ser interpretado de forma a corrigir a evidente desvalorização histórica. Desse modo, ao fixar o valor dos honorários periciais, o Juízo deverá respeitar, obrigatoriamente, a correção monetária.

Muito bem avalia Francisco Meton Marques de Lima e Francisco Péricles Rodrigues Marques de Lima (2017), acerca da Lei n 13.467/2017 que

\begin{abstract}
cumpre observar que a lei vai dificultar as perícias, principalmente nos processos de menor valor e de pessoas mais simples, mormente sem adiantamento de uma parte para as despesas iniciais. $\mathbf{O}$ valor de $\mathbf{R} \mathbf{\$}$ $1.000,00$ é irrisório para remunerar qualquer profissional de perícia, é o valor de uma consulta médica especializada de dez minutos. Com isso, os juízes terão que usar sua criatividade para viabilizar as perícias. (LIMA E LIMA, 2017, p. 120, grifo nosso).
\end{abstract}

No campo pericial médico, a Resolução do Conselho Regional de Medicina do Espírito Santo (CRM/ES) n² 265/2016, estabelece o valor da Hora Técnica (HT) para realização de perícias médicas solicitadas pelo Poder Judiciário e da outras providências, instituindo o valor de $R \$ 360,00$ (trezentos e sessenta reais) como o valor da Hora Técnica $(\mathrm{HT})$, sendo aplicável nacionalmente por força do art. 18 do 
Código de Ética Médica. E, o parágrafo único do art. 98 do Código de Ética Médica determina que o médico tem direito a justa remuneração pela realização do exame pericial.

Bem verdade que para evitar a uberização dos peritos judiciais trabalhistas, cabível a criação da carreira pública de Perito Médico Judicial na Justiça do Trabalho.

Nessa matéria, dispõe o juiz do trabalho Mauro Schiavi (2016) que:

o ideal seria que a Justiça do Trabalho tivesse peritos concursados e remunerados pelo Estado, a fim de dar maior credibilidade à prova pericial e evitar todas as vicissitudes decorrentes do pagamento dos honorários periciais. (SCHIAVI, 2016, p. 793).

Assim, a solução é única: criar a carreira de Perito Médico Judicial imediatamente. E, todas as luzes estão direcionadas ao TST, que deve propor um Projeto de Lei, nos termos do artigo 96, inciso II, alínea "b", da Constituição Federal de 1988, com aprovação pelo CSJT e do Conselho Nacional de Justiça (CNJ), nos termos do inciso IV do art. 102 da Lei n 13.408/2016, para dispor sobre a criação do cargo de Perito Médico Judicial no quadro efetivo de pessoal da Justiça do Trabalho, frente às necessidades de aperfeiçoamento da prestação jurisdicional e ao cumprimento da missão institucional da Justiça do Trabalho de forma célere, moral e efetiva à sociedade.

\section{CONSIDERAÇÕES FINAIS}

As alterações promovidas pela lei processual civil brasileira apresentam repercussões na seara da Justiça do Trabalho, diante de encontrar, em situações de omissão e compatibilidade aplicação no processo do trabalho. Nessa senda, cabe atualização da jurisprudência consolidada do órgão de cúpula para buscar a aplicabilidade efetiva do CPC de 2015 no que concerne ao processo do trabalho, garantindo, assim como os demais ramos do Poder Judiciário. 
Apresentou-se, com enfoque nas alterações do CPC de 2015 e da Lei $n^{\circ}$ 13.467/2017 na matéria da prova pericial e dos honorários periciais, revelando a responsabilidade do Poder Judiciário Trabalhista na correta aplicação da interpretação da Lei, para garantir o acesso a justiça e o respeito ao digno trabalho do Perito Judicial Trabalhista. Os Tribunais devem garantir que o Perito do Juízo receba o adiantamento dos honorários periciais, mesmo que por requisição antecipada mediante a União, sob pena de flagrante injustiça, negativa da prestação jurisdicional e aumento da precarização do trabalho do Perito do Juízo.

Verificou-se que, de forma exemplificativa, foram significativos os reflexos do Código de Processo Civil de 2015 no processo do trabalho, cabendo a jurisprudência trabalhista promover seu aperfeiçoamento, em sintonia com a preservação da segurança jurídica, condição essencial em uma sociedade democrática.

\section{REFERÊNCIAS}

ALVES, Daniel Amorim Assumpção. Direito Processual Civil. São Paulo: Método, 2015.

BRASIL. Código de Processo Civil. Disponível em: < http://www.planalto.gov.br/ccivil_03/_ato2015-2018/2015/lei//13105.htm> Acesso em 19 set. 2017.

Consolidação das Leis do Trabalho. Disponível em: < http://www.planalto.gov.br/ccivil_03/decreto-lei/Del5452.htm> Acesso em 19 set. 2017.

Constituição da República de 1988. Disponível em: < http://www.planalto.gov.br/ccivil_03/constituicao/constituicaocompilado.htm> Acesso em 21 set.. 2017.

. Lei $n^{\circ}$ 13.467, de 13 de julho de 2017. Diário Oficial da União, Brasília, DF, 14 set. 2017. 
CONSELHO FEDERAL DE MEDICINA. Resolução n. 2.056/2013. Disponível em: < http://www.portalmedico.org.br/resolucoes/CFM/2013/2056_2013.pdf> Acesso em 15 out. 2017.

DIDIER JÚNIOR, Fredie. Do recurso de terceiro prejudicado. Disponível em: < http://www.unifacs.br/revistajuridica/arquivo/edicao_junho2001/corpodocente/recurso .htm> Acesso em: 17 out. 2017.

GARCIA, Gustavo Filipe Barbosa. Novo CPC e o Processo do Trabalho: conforme Lei 13.467/2017 - Reforma Trabalhista. 3 ed. Salvador: JusPODVIM, 2017.

LIMA, Francisco Meton Marques de; LIMA, Francisco Péricles Rodrigues Marques de. Reforma Trabalhista. São Paulo: LTr, 2017.

OLIVEIRA, Sebastião Geraldo. Indenizações por acidente do trabalho ou doença ocupacional. São Paulo: LTr, 2013.

SCHIAVI, Mauro. Direito Processual do Trabalho. 11 ed. São Paulo: LTr, 2016.

SOARES, Saulo Cerqueira de Aguiar; SOARES, Ivna Maria Mello. O trabalho precário do perito médico judicial trabalhista. In: Fluxo de Direito e Processo do Trabalho. SOARES, Saulo Cerqueira de Aguiar Soares; EÇA, Vitor Salino de Moura. Curitiba: CRV, 2017.

SOARES, Saulo Cerqueira de Aguiar. Direitos Fundamentais do Trabalho. São Paulo: LTr, 2017.

TRIBUNAL REGIONAL DO TRABALHO DA 18 REGIÃO. Pleno do TRT reconhece legalidade de depósito prévio para realização de perícia. Disponível em: < http://www.trt18.jus.br/portal/noticias/pleno-do-trt-reconhece-legalidade-de-depositoprevio-para-realizacao-de-pericia/> Acesso em: 15 out. 2017. 